\title{
Drip Irrigation in the Tropics: Evidence from South India
}

\author{
Pre-Analysis Plan \\ Ram Fishman, Tel Aviv University \\ Xavier Giné, World Bank \\ Hanan Jacoby, World Bank
}

\begin{abstract}
Water scarcity is one of the fundamental challenges facing developing country agriculture. In South Asia, millions of privately-owned borewells have sprung up in the last two decades, to the point where groundwater has become the largest irrigation source in India, especially vital for dry season cultivation. While groundwater exploitation has contributed significantly to poverty reduction in rural India, unregulated drilling has also raised concerns about the sustainability of this crucial resource. Widespread adoption of drip irrigation has been proposed as a promising water-saving solution to the problem of groundwater over-exploitation. However, there is little, if any, rigorous evidence on its benefits, both in terms of agricultural production and potential water savings. We implement a randomized control trial, in which a treatment group of borewell owners was encouraged to adopt drip irrigation against a control group that kept the status quo. The study will track agricultural production, farm income, and water use in both groups before and after drip adoption.
\end{abstract}

Keywords: Water-saving Technology; Groundwater Depletion; Agricultural Productivity JEL codes: $\mathrm{O} 13$. 


\section{STUdy OVERVIEW}

Faced with a looming groundwater crisis, India is now promoting water-efficient cultivation by offering 50\%-90\% subsidies on drip and sprinkler irrigation systems, technologies that promise to increase crop productivity while simultaneously reducing per acre water requirements. Yet, there is a paucity of experimental evidence on the actual performance of these technologies when used by smallholder farmers in their own plots. In addition, an improvement in water-use efficiency does not necessarily reduce overall water consumption. In a context where agricultural land remains idle or underutilized, as in much of India during the dry season, and especially where groundwater markets are active, farmers may adjust their water application along the extensive margin to leave overall groundwater pumping unchanged. Moreover, the increased value of water could also theoretically lead to an increase in utilization of the resource, resulting in a rebound effect.

This study will employ a randomized control trial built upon an already scaled-up subsidy scheme in Andhra Pradesh to measure the impact of drip irrigation adoption on water use, cultivation patterns, water sales, agricultural productivity, and farmer income. In so doing, the study will provide the first experimental evidence on the benefits of drip irrigation to smallholder farmers. This will allow a cost-benefit analysis of India's micro irrigation policy of massive subsidies. Above all, the study will assess whether widespread adoption of watersaving technologies can arrest groundwater depletion.

\section{BACKGROUND}

Overview

India is the world's largest user of groundwater (Aeschbach-Hertig and Gleeson 2012). Groundwater irrigation covers more than half of the total irrigated area, is responsible for $70 \%$ of production, and supports some 50\% of the population (Langseth and Stapenhurst 1998; Shah 2010). However, it is now becoming clear that over-extraction of groundwater is depleting aquifers across the country (Rodell et al. 2009; Tiwari et al. 2009; World Bank 2009; Shah 2009). Pricing of water (and the energy used to pump it) at its social cost (shadow price) is the efficient way to manage the resource, but political and technical constraints often prohibit pricing, especially in developing countries. In India, groundwater is neither regulated nor priced, and even the electricity used for pumping is heavily subsidized and often priced at a flat tariff, if at all (Badiani et al., 2012).

In lieu of pricing, India has moved toward promotion and subsidization of water-efficient cultivation technologies. India's National Mission on Micro Irrigation (NMMI) is perhaps the largest such program in the world, offering 50\%-90\% subsidies on drip and sprinkler irrigation, technologies that promise to increase crop productivity and simultaneously reduce per acre water requirements. The potential of these technologies to avert and adapt to a growing global water crisis has been hailed by scientists, economists, and policymakers alike (Postel 2001, Tilman 2002, Foley et al 2011). However, in 2001, only 3\% of India's some 8.5 million borewell owners used drip or sprinkler irrigation; $88 \%$ delivered water to their crops by flooding through open channels. The NMMI, as enunciated in its operational guidelines, seeks to increase diffusion of water-efficient irrigation so as to "save water, power, fertilizer consumption, weeding cost, etc..." 


\section{Research question}

The proposed research will examine the impact of drip irrigation adoption on water use, cultivation patterns, water sales, agricultural productivity, and farmer income. Indeed, this study will provide the first experimental evidence on the benefits of drip irrigation to smallholder farmers and, in so doing, will allow a cost-benefit analysis of India's micro irrigation policy. Above all, the study will assess whether widespread adoption of watersaving technologies can actually arrest groundwater depletion.

In theory, an improvement in water-use efficiency may not reduce overall water consumption. Since water supply is constrained by the rationed supply of electrical power for pumping, borewell-owning farmers may leave some of their land fallow in the dry season or cultivate crops with low water requirements. Famers on neighboring plots, with or without borewells, may be similarly constrained. As irrigation efficiency improves (via drip adoption), the water constraint ceases to bind and farmers may adjust by cultivating more of their land previously left fallow, by switching to more water-intensive crops, or by selling excess water to their neighbors, who may then similarly adjust. In principle, these responses to drip could continue until the water constraint becomes binding once again, leaving the rate of pumping unchanged. In practice, however, transactions costs in groundwater markets may limit water sales. Related, the response to drip will depend on the extent to which the local groundwater market is saturated. If it is, then the impacts of drip adoption are likely to be more muted.

In short, the impact of drip irrigation on overall water use is an open empirical question, one with substantial practical implications for India's agriculture and the state of its groundwater resources.

\section{Intervention and mode of delivery}

Subsidies on drip irrigation are distributed through a partnership of India's central and state governments. The Centrally Sponsored Scheme, released in 2005-06, provides $40 \%$ of drip costs, contingent on an additional $10 \%$ or more being offered by state governments. There is considerable variation in both the level of subsidy and the delivery of drip subsidies across states. Andhra Pradesh, the state in which this study will be carried out, has recently increased is subsidy share to $50 \%$, making for a total subsidy of $90 \%$. The overall amount a farmer can receive is capped at levels that depend on land holdings. For the smallest total land holding category ( $<10$ acres), the cap is 100,000 Rs. per farmer, which allows for a 2 acre drip system, depending on the crop in question and other technical parameters. Farmers who have availed themselves of the subsidy in the past are ineligible to receive additional subsidies for a period of 10 years.

Government certified commercial suppliers can sell drip equipment to farmers at regulated prices and be eligible for the subsidy. In particular, the farmer applies for the subsidy at a local government agency, a process that is often facilitated by the supplier, and involves the submission of documents establishing land ownership and a legal electricity connection for the pump. Once the farmer pays his share (10\%) and the application is approved, the drip supplier installs the equipment. Finally, once the government verifies the installation, the remaining $90 \%$ of the costs are transferred directly to the supplier. 
The study takes place in three districts of Andhra Pradesh (Anantapur, Kadapa, and Guntur) and was carried out in cooperation with Jain Irrigation (JI), the largest provider of drip irrigation in India.

Farmers who have availed themselves of the subsidy in the past are ineligible to receive additional subsidies for a period of 10 years. A filter survey was therefore administered in January 2016 to determine eligibility, which depends on owning less than 10 acres of land, having not availed of this subsidy in the past ten years and having official proof of land ownership (land passbook) and a legal electricity connection for the borewell.

\section{LITERATURE REVIEW}

There have been numerous agronomic studies of drip irrigation impacts, some of which are set in developing countries (e.g., Narayanamoorthy, 2004; Sezen et al. 2006; Kumar and Palanisami, 2010, and work cited therein). These studies often find shifts in cropping patterns, higher yields and higher water productivity, but are mostly based on small samples and do not deal with selection bias. Specifically, farmers who take up drip irrigation are likely to be more progressive and risk-taking and, therefore, may cultivate more intensively and extensively even in the absence of drip. An exception is Burney et al. (2010), which addresses selection using difference-in-differences to find large income and nutritional impacts of collective systems of drip irrigation in two villages in Benin. Critically, however, no developing country study of drip irrigation considers farmer responses along the extensive margin, the role of groundwater markets, or distinguishes partial and general equilibrium effects.

Multiple studies have assessed whether water-saving technology can arrest groundwater depletion in the US context, mostly using integrated hydrological-economic-agricultural models calibrated on river basins (Ward and Pulido-Velazquez 2008, Peterson and Ding 2005, Huffaker and Whittlesey 2003, Scheierling et al 2006, Huffaker and Whittlesey 2000). Other, principally theoretical work, considers the interaction between water markets and the adoption of water-saving technologies; it too is confined exclusively to the US context (Carey and Zilberman 2002; Dridi and Khanna 2005). In an important study, Pfeiffer and Lin (2014) use panel data from Kansas to find that adoption of water-efficient center pivot irrigation led to an increase in groundwater use through both a decrease in fallow and a shift to more water-intensive crops. Groundwater markets, however, are not relevant in this setting. In the context of India, Fishman, Devineni and Raman (2015) show that farmer cultivation response has the potential to greatly mitigate the groundwater-saving impact of drip adoption, but, as noted, there is virtually zero evidence on the magnitude of this response in practice.

\section{THEORY OF CHANGE}

The intervention will induce or encourage farmers to adopt drip irrigation on some fraction of their borewell irrigated land, which will increase irrigation efficiency (crop yield per unit of water applied) on that land by a factor of two at least. By maintaining optimal moisture, drip irrigation enhances plant growth. Moreover, by directing moisture to the plant, it suppresses weed growth, which saves labor. Finally, drip allows fertigation (combined fertilization with 
irrigation), which also saves labor. All three of these effects contribute to higher profits per acre with drip irrigation as compared with traditional flood or furrow irrigation (see Figure 1).

In theory, the increase in irrigation efficiency induced by drip will save groundwater. However, farmers are also expected to adjust on the intensive and extensive margins. On the intensive margin, by switching to more water intensive crops that could not feasibly be irrigated prior to drip. On the extensive margin, by cultivating more of the plot, to the extent that some land was left fallow in the absence of drip, or by selling water to a neighboring farmer with plot that would otherwise be left fallow or underutilized. While these behavioral responses increase the income of the drip adopter (as well as, possibly, that of the neighboring farmers), they do not lead to a reduction in groundwater pumping. Farmers will continue to pump the maximum number of hours given by their electricity supply.

As noted in Figure 1, the critical preconditions for expansion of dry season cultivation, either on the farmer's own land or on that of a neighbor, is that such land is not already irrigated by other borewells and, in the second case, that groundwater markets also function efficiently. Transactions costs and other distortions in groundwater markets (see Giné and Jacoby, Forthcoming) limit the ability of a farmer to adjust along the extensive margin and could thus increase the water-saving impact of drip adoption. ${ }^{1}$ Finally, the demand for irrigation by neighboring farmers depends not only on their borewell ownership, but also on the waterefficiency of their irrigation. Thus, to the extent that drip systems are also adopted on neighboring plots, a farmer converting to drip will confront a lower demand for groundwater just as his own supply has effectively been increased. In other words, in general equilibrium any drip-induced expansion in water sales is likely to be attenuated relative to that which would occur in partial equilibrium (i.e., when only an isolated farmer adopts drip).

\section{Hypotheses/Evaluation Questions}

\section{Hypotheses}

1. Installation of drip irrigation on the reference borewell increases crop yield, reduces labor and fertilizer costs, raises crop profits.

2. Installation of drip irrigation on the reference borewell leads farmers to increase irrigation use of other land owned by the farmer in both the extensive and intensive margins:

a. Expand irrigation from the reference borewell to other land in reference plot previously left fallow or other land owned by the farmer nearby.

b. Switch to more water-intensive crops on reference plot or adjacent lands.

c. Increase the frequency of irrigations.

3. Installation of drip irrigation on the reference borewell increases the likelihood and amount of water transfer to neighboring land

a. The likelihood and amount of water sales increase.

b. The likelihood and amount of land leased in by the reference farmer increase.

c. Outcomes 3.a and 3.b is more likely when:

i. Neighboring farmers are water-constrained (not fully irrigating their land).

ii. The neighboring and reference farmer have a history of water transactions.

\footnotetext{
${ }^{1}$ Another margin along which farmers may adjust is by drilling additional borewells, insofar as an increase in irrigation efficiency raises the return to well-drilling. However, as borewell investment entails substantial upfront outlays, we do not expect to observe a significant response along this margin over the time-frame of the study.
} 
iii. The reference farmer land is fully irrigated with wet crops.

4. Installation of drip irrigation on the reference borewell will lead to more water savings if all plots in the adjacency are fully irrigated with wet crops.

\section{Evaluation Questions}

1. Can widespread adoption of water-saving irrigation technology arrest groundwater depletion?

2. What are the economic returns to drip irrigation adoption and do they justify massive state subsidies?

3. How do groundwater markets condition the water-savings and economic returns to drip?

6. MAIN OUTCOMES OF INTEREST

1. Indicators for the reference plot:

a. Crop choice (Crop grown is wet).

b. Irrigation

i. Extensive margin: total area cultivated and irrigated.

ii. Intensive margin: area cultivated with wet and dry crops and frequency of irrigation.

c. Detailed input use, especially fertilizer and labor.

d. Yield, revenue, cost (especially fertilizer and labor), profit for past 4 dry seasons, spanning seasons before and after adoption of drip irrigation.

e. Price of crops.

2. Indicators for area adjacent to reference plot:

a. Land leased in by owner of reference plot.

b. Crop choice (Crop grown is wet).

c. Irrigation

i. Extensive margin: total area cultivated and irrigated.

ii. Intensive margin: area cultivated with wet and dry crops and frequency of irrigation.

3. Whether owners of adjacent plots have drilled well.

4. Whether owners of adjacent plots have adopted drip irrigation.

5. Indicators for reference borewell

a. number of days and hours in operation (pumping).

b. Water sales

i. Whether any was sold.

ii. Area irrigated and nature of contract.

6. Perceptions:

a. Difference in investment and production with/without drip irrigation.

b. Trust in drip irrigation companies and government institutions.

c. Constraints on production (emphasis on water vs. other constraints).

d. Cost of drip irrigation and reasons for not taking it up (for non-compliers).

7. Farm assets.

7. Evaluation Design and SAmpling Strategy 


\subsection{TREATMENT AND CONTROL GRoups}

The experiment consists of a treatment and a control group. The treatment will entail the offer of subsidized drip adoption on the reference borewell plot (red) for eligible farmers. As noted, the installation of a drip system of 2 acres involves a total investment of around 100,000 Rs. (10\% of which will be subsidized through the experimental intervention). We will identify the effect of drip irrigation by comparing the outcomes in the reference plot or borewell of farmers in the treatment group against the same outcomes for farmers in the control group that did not receive the offer of the subsidy for drip adoption.

Table 1 presents the balance checks using data from the filter and baseline survey (see section 9.1). We note that only filter data were available at the time of randomization. Panel A uses the sample of 1,153 farmers with filter survey data and we find that while wells owned by farmers in the treated group tend to have smaller reference plots, overall there is balance between the treatment and control groups (p-value of F-stat of joint significance is 0.266). Panel B restricts the sample to 862 farmers that are eligible for the subsidy and we still find overall balance (p-value is 0.349 ). These are farmers that did not avail the subsidy previously, that have all the land records needed to apply and that have a functioning borewell. Panel $\mathrm{C}$ reports balance on the owner and reference plot and well characteristics from the baseline survey using the sample of eligible farmers. There are differences in the probability that the treatment group grew wet crops in the previous Rabi and in the borewell's pipe width. The treatment group is 5\% less likely to grow wet crops and has slightly smaller pipe width. Although the difference in pipe width is statistically significant, it is small. Taking all the characteristics from the baseline survey together, there appears to be some imbalance between the treatment and control group ( $\mathrm{p}$ value of F-stat of joint significance is 0.036). We will follow McKenzie and Bruhn (2009) and include as control variables in the analysis those characteristics that are imbalanced.

\subsection{SAmple Size CAlculations}

Sampling must account for the localized nature of groundwater markets; the vast majority of these transactions occur between adjacent plots. Thus, the highest unit of analysis for the study will be the adjacency of the reference borewell, that is, the plots adjacent to the reference plot as illustrated by the area within the red double thin lines in Figure 2. Our sampling frame will be drawn from the 2012 Groundwater Markets Survey (henceforth GMS; see Giné and Jacoby, Forthcoming). As in that survey, the owner of the reference borewell will be surveyed with reference to his plot (red cell), but he will also report on water transfers to any of the adjacent plots (orange cells). No information will be collected on the outer ring of plots (yellow cells).

Based on GMS data, there are typically 4 plots in the adjacency, and inclusive of the reference borewell, there are 2-3 wells within an adjacency (mean is 2.5) on average, as indicated by the solid blue circles in Figure 2. In addition, around $66 \%$ of plots in the adjacency (excluding the reference plot) are cultivated during Rabi, and around 51\% of plots in the adjacency (again excluding the reference plot) have a functioning well. 
Based on the 2012 GMS data, Table 2 reports minimum detectable effects (MDEs) at 80\% power and 5\% significance using the actual number of eligible adjacencies. The outcomes considered are the total area irrigated by the reference well, the share of the reference plot area under wet crops, the probability that the well owner sells water to an adjacent plot, and the area irrigated under a water contract. ${ }^{2}$

The minimum detectable effects or MDEs is the minimum increase that is detectable given the sample size of 862 farmers. Put differently, we report the minimum (higher) value that the mean of an outcome variable can take that would be statistically different from the mean at baseline. For example, at baseline the reference well irrigated a total of 3.1 acres, on average. If under drip irrigation the reference well increases the total area irrigated to at least 3.3 acres, or a $6 \%$ increase, we would be able to detect such increase statistically given the sample size. Similarly, our ability to detect increases in the fraction of area under wet crops is limited as we can only detect an increase of $33 \%$, from 8 percent to 10 percent. The upshot of this analysis is that our sample of 862 borewells provides tolerable power for some of our key outcomes. ${ }^{3}$

\section{NON COMPLIANCE}

By February 2019, 40\% of the treatment farmers had drip systems installed on their lands. The remaining treatment farmers did not have drip installed for various reasons. One reason could be lack of interest in drip as the farmer had a perennial crop planted in the reference plot. Another reason for non-compliance is the drying up of reference borewells. Data from the follow-up survey may allow us to identify the occurrence of this event among both the treatment and control group.

\section{Data Collection}

The study sample draws borewell owners from two of the six districts covered by the 2012 GMS. Before implementing the baseline, however, we need to verify that the original GMS respondents still have a functioning borewell, that they have not yet adopted drip irrigation, and that they are otherwise eligible to avail the NMMI subsidy. All in all, we will collect three rounds of survey data: (i) a filter survey to determine eligibility; (ii) a baseline among eligible borewell owners; and (iii) an end-line survey two years after the drip intervention.

\subsection{QUANTITATIVE INSTRUMENTS}

\section{Filter survey}

The filter survey was used to determine whether the respondent is eligible for the largest subsidy (has < 10 acres landholdings and has not availed a subsidy in last 10 years) and whether he has a single irrigated plot with a single individually-owned (still functional) borewell. We did not consider individuals with multiple irrigated plots (about $15 \%$ of

\footnotetext{
${ }^{2}$ Crops grown in these areas can be classified into wet and irrigated dry (ID) depending on their water requirements. For example, paddy and mulberry are wet crops, whereas groundnut and chilies are ID crops.

${ }^{3}$ Unfortunately, the GMS does not provide information on hours of pumping nor on crop production.
} 
borewell owners) because they may want to use the subsidy to install drip irrigation on a plot different from that of the reference borewell. Similarly, we did not use co-owned wells as reference borewells. In addition, the respondent was asked whether he had the proper documentation (a land passbook and a legal electricity connection for the borewell). Filter survey data was used as a basis for selecting study participants and for randomization into treatment or controls.

\section{Baseline survey}

A baseline survey was administered in 2016 amongst the sample of 993 eligible farmers. The survey covered agricultural production on the reference borewell plot over the previous dry (rabi) season, including area irrigated, crops grown, investment in seeds, fertilizer and labor, yields, hours of borewell operation (if one is present on the plot) and details of all water transactions with adjacent plots.

\section{Endline survey}

The follow-up survey is being administered in August 2019 and is similar to the baseline, except that irrigation, cultivation and production data will be collected from all plots in the adjacency over the last four dry seasons since 2015-6 to 2018-19. In addition, the survey includes modules on satisfaction with drip irrigation and plans to expand area irrigated by drip, to change farming practices, and to drill new borewells.

\section{ANALYSIS}

For expositional clarity, we focus here on ITT estimates, but in practice we will obtain TT estimates using instrumental variables. Drip impacts on reference borewell/plot-level outcomes (cf. Section 6) will be estimated using the following specification:

$$
Y_{i 1}=\alpha T_{i}+X_{i}^{\prime} \beta+\gamma Y_{i 0}+\varepsilon_{i}
$$

where $Y_{i 1}$ refers to an outcome of borewell, plot or adjacency $i$ at endline, $T_{i}$ is a dummy that takes value 1 if borewell $i$ had been offered the subsidy for drip irrigation, that is, was in the treatment group, and $X_{i}$ is a vector of adjacency, plot or well characteristics at baseline, including those that are imbalanced. Note that controlling for baseline outcomes is more general than the alternative of difference-in-differences. The parameter of interest is $\alpha$, which represent the impacts and responses to drip irrigation installation. Since we collect 4 years of data for area irrigated in the reference plot, production and costs, for these outcomes we can use the following specification

$$
Y_{i t}=\alpha_{t} T_{i t}+X_{i}^{\prime} \beta+\gamma Y_{i 0}+\varepsilon_{i t}
$$

where $Y_{i t}$ refers to plot $i$ outcome at time $t, T_{i t}$ now denotes a dummy that takes value 1 if borewell $i$ at time $t$ had been offered the subsidy for drip irrigation. The parameter of interest is now $\alpha_{t}$, which can be allowed to vary by year or be restricted to a single parameter. 
For continuous outcomes, which most of ours are, we will use OLS or linear IV for the TT estimates. When the dependent variable is binary, such as whether a sale of water occurred, we will use logit or probit (or probit IV for the TT). Given the very low mobility in our study area and the fact that farmers, in particular, are tied to their land, we do not expect significant attrition problems over the three year study. Finally, the outcomes described in Section 6 are sufficiently distinct that multiple hypothesis testing should not be an issue.

A heterogeneity analysis will be used to test hypotheses 3.c and 4 by adding to the basic specification in (1) interactions between the treatment variable and reference plot or adjacency characteristics at baseline (e.g., plot being fully irrigated, number of borewells, fraction of land fallow in adjacency, structure of groundwater markets) as measured at baseline:

$Y_{i 1}=\alpha T_{i}+\delta T_{i} x H_{i}+X_{i}^{\prime} \beta+\gamma Y_{i 0}+\varepsilon_{i}$

where $H$ is the predictor of heterogeneity.

\section{REFERENCES}

Aeschbach-Hertig, W., \& Gleeson, T. (2012). Regional strategies for the accelerating global problem of groundwater depletion. Nature Geoscience 5(12): 853-861.

Badiani, R., Jessoe, K. K., \& Plant, S. (2012). Development and the environment: the implications of agricultural electricity subsidies in India. The Journal of Environment \& Development, 1070496512442507.

Bruhn, M. and D. McKenzie. (2009). In Pursuit of Balance: Randomization in Practice in Development Field Experiments. American Economic Journal: Applied Economics 1(4): 200232.

Burney, J., Woltering, L., Burke, M., Naylor, R., \& Pasternak, D. (2010). Solar-powered drip irrigation enhances food security in the Sudano-Sahel. Proceedings of the National Academy of Sciences 107(5): 1848-1853.

Carey, J. M., \& Zilberman, D. (2002). A model of investment under uncertainty: modern irrigation technology and emerging markets in water. American Journal of Agricultural Economics 84(1): 171-183.

Dridi, C., \& Khanna, M. (2005). Irrigation technology adoption and gains from water trading under asymmetric information. American Journal of Agricultural Economics 87(2): 289-301. Fishman, R., Devineni, N., \& Raman, S. (2015). Can improved agricultural water use efficiency save India's groundwater?. Environmental Research Letters 10(8): 084022.

Foley, J. A., Ramankutty, N., Brauman, K. A., Cassidy, E. S., Gerber, J. S., Johnston, M., ... \& Zaks, D. P. (2011). Solutions for a cultivated planet. Nature 478(7369): 337-342.

Giné, X. \& Jacoby, H. (2015). Markets, Contracts and Uncertainty: A Structural Model of a Groundwater Economy, unpublished manuscript, World Bank, Washington DC.

Huffaker, R., \& Whittlesey, N. (2000). The allocative efficiency and conservation potential of water laws encouraging investments in on-farm irrigation technology. Agricultural Economics 24(1): 47-60. 
Huffaker, R., \& Whittlesey, N. (2003). A theoretical analysis of economic incentive policies encouraging agricultural water conservation. International Journal of Water Resources Development 19(1): 37-53.

Kumara, D. S., \& Palanisamib, K. (2010). Impact of drip irrigation on farming system: evidence from southern India.

Langseth, P., \& Stapenhurst, R. (1998). India-Water resources management sector review: groundwater regulation and management report.

Narayanamoorthy, A. (2004). Impact assessment of drip irrigation in India: the case of sugarcane. Development Policy Review 22(4): 443-462.

Peterson, J. M., \& Ding, Y. (2005). Economic adjustments to groundwater depletion in the high plains: Do water-saving irrigation systems save water? American Journal of Agricultural Economics 87(1): 147-159.

Pfeiffer, L., \& Lin, C. Y. C. (2014). Does efficient irrigation technology lead to reduced groundwater extraction? Empirical evidence. Journal of Environmental Economics and Management 67(2): 189-208.

Postel, S., Polak, P., Gonzales, F., \& Keller, J. (2001). Drip irrigation for small farmers: a new initiative to alleviate hunger and poverty. Water International 26(1), 3-13.

Rodell, M., Velicogna, I., \& Famiglietti, J. S. (2009). Satellite-based estimates of groundwater depletion in India. Nature 460(7258): 999-1002.

Scheierling, S. M., Young, R. A., \& Cardon, G. E. (2006). Public subsidies for water-conserving irrigation investments: Hydrologic, agronomic, and economic assessment. Water Resources Research 42(3).

Sezen, S. M., Yazar, A., \& Eker, S. (2006). Effect of drip irrigation regimes on yield and quality of field grown bell pepper. Agricultural Water Management 81(1): 115-131.

Shah, T. (2009). Climate change and groundwater: India's opportunities for mitigation and adaptation. Environmental Research Letters 4(3), 035005.

Shah, T. (2010). Taming the anarchy: Groundwater governance in South Asia. Routledge. Tilman, D. (1999). Global environmental impacts of agricultural expansion: the need for sustainable and efficient practices. Proceedings of the National Academy of Sciences 96(11), 5995-6000.

Tiwari, V. M., Wahr, J., \& Swenson, S. (2009). Dwindling groundwater resources in northern India, from satellite gravity observations. Geophysical Research Letters 36(18). World Bank (2009). Deep wells and prudence: towards pragmatic action for addressing groundwater overexploitation in India. Report, World Bank.

Ward, F. A., \& Pulido-Velazquez, M. (2008). Water conservation in irrigation can increase water use. Proceedings of the National Academy of Sciences 105(47): 18215-18220. 
Figures and Tables

Induced activity

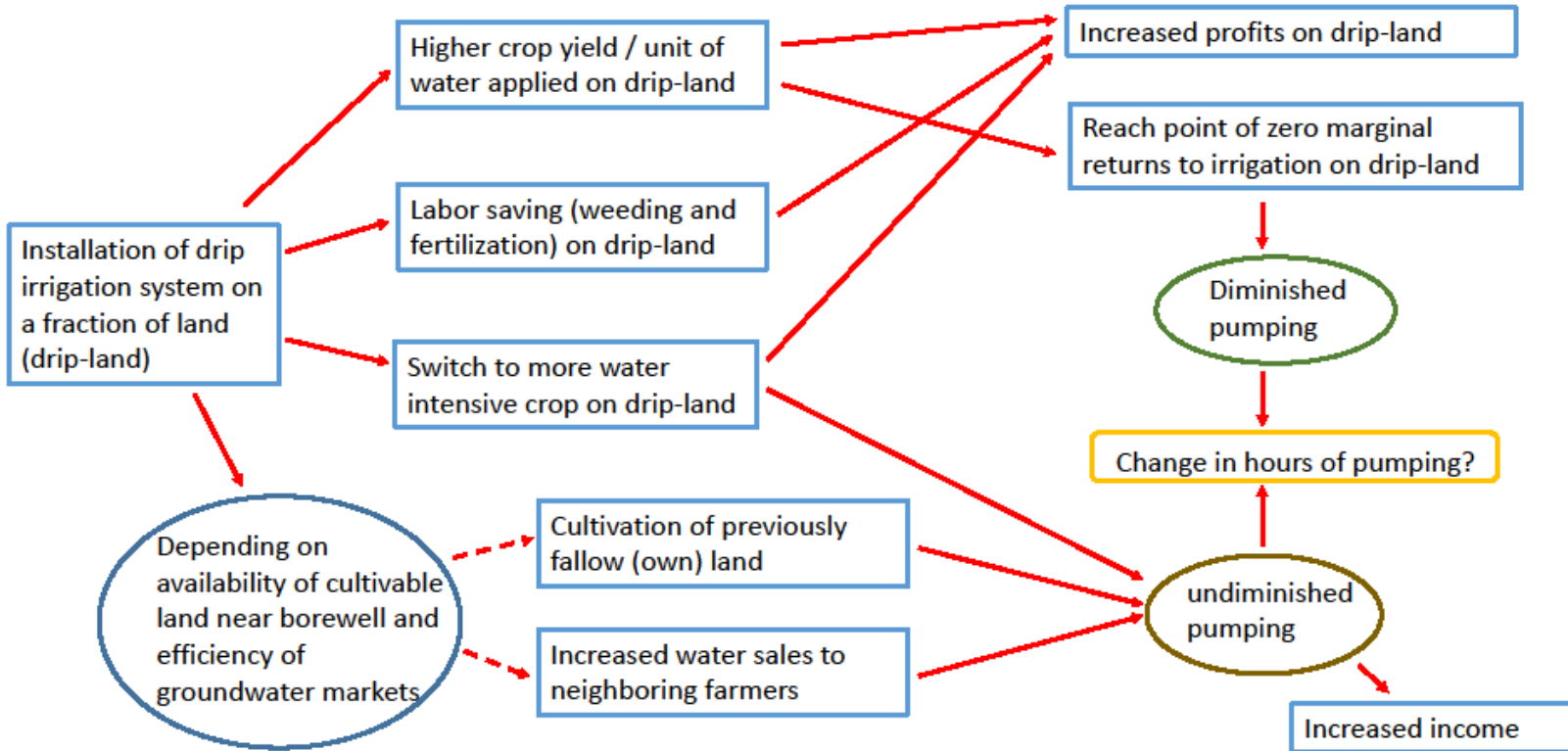

Figure 1: Theory of change

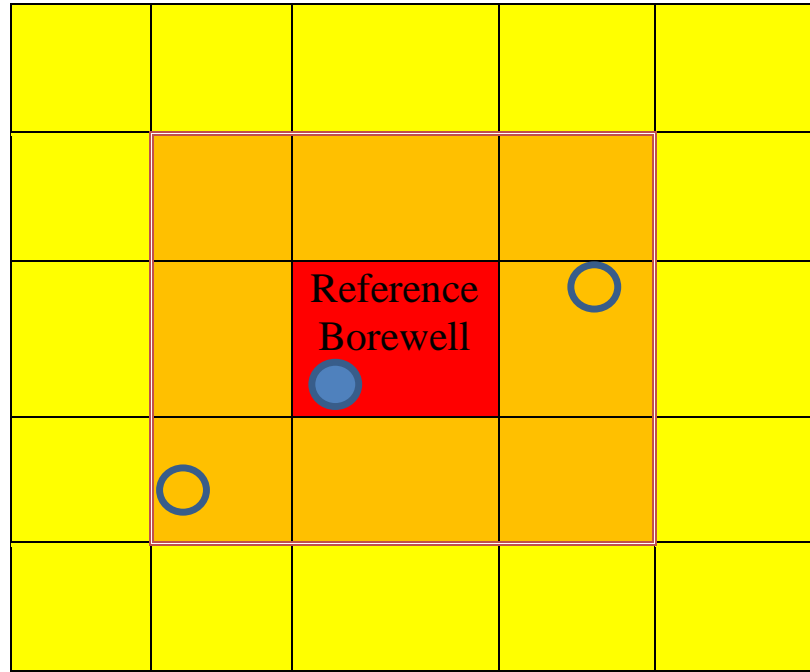

Figure 2: Schematic of an adjacency with treatments 


\begin{tabular}{|c|c|c|c|c|}
\hline & (1) & (2) & (3) & \\
\hline & All & Control & Treatment & $\begin{array}{c}\text { p-value (2) } \\
\text { (3) }\end{array}$ \\
\hline \multicolumn{5}{|l|}{ Panel A: Filter survey, all farmers } \\
\hline \multicolumn{5}{|l|}{ Characteristics of plot owner } \\
\hline Family total landholdings (acres) & $\begin{array}{c}0.160 \\
{[0.011]}\end{array}$ & $\begin{array}{c}0.165 \\
{[0.015]}\end{array}$ & $\begin{array}{c}0.155 \\
{[0.016]}\end{array}$ & 0.712 \\
\hline \multicolumn{5}{|l|}{ Characteristics of reference plot } \\
\hline Reference plot area (acres) & $\begin{array}{c}0.587 \\
{[0.015]}\end{array}$ & $\begin{array}{c}0.607 \\
{[0.019]}\end{array}$ & $\begin{array}{c}0.562 \\
{[0.022]}\end{array}$ & $0.032 * *$ \\
\hline \multicolumn{5}{|l|}{ Characteristics of main well in the reference plot } \\
\hline Well was sunk after 2011 (1=Yes) & $\begin{array}{c}1.939 \\
{[0.024]}\end{array}$ & $\begin{array}{c}1.937 \\
{[0.030]}\end{array}$ & $\begin{array}{c}1.943 \\
{[0.037]}\end{array}$ & 0.345 \\
\hline Well is individually owned ( $1=$ Yes $)$ & $\begin{array}{c}2.952 \\
{[0.046]}\end{array}$ & $\begin{array}{c}2.966 \\
{[0.062]}\end{array}$ & $\begin{array}{c}2.934 \\
{[0.069]}\end{array}$ & 0.585 \\
\hline Number of observations & & & & 1,193 \\
\hline F-test of joint significance (p-value) & & & & 0.266 \\
\hline \multicolumn{5}{|l|}{ Panel B: Filter survey, eligible farmers } \\
\hline \multicolumn{5}{|l|}{ Characteristics of plot owner } \\
\hline Family total landholdings (acres) & $\begin{array}{c}0.161 \\
{[0.013]}\end{array}$ & $\begin{array}{c}0.169 \\
{[0.017]}\end{array}$ & $\begin{array}{c}0.151 \\
{[0.018]}\end{array}$ & 0.526 \\
\hline \multicolumn{5}{|l|}{ Characteristics of reference plot } \\
\hline Reference plot area (acres) & $\begin{array}{c}0.635 \\
{[0.016]}\end{array}$ & $\begin{array}{c}0.657 \\
{[0.022]}\end{array}$ & $\begin{array}{c}0.608 \\
{[0.025]}\end{array}$ & $0.047 * *$ \\
\hline \multicolumn{5}{|l|}{ Characteristics of main well in the reference plot } \\
\hline Well was sunk after 2011 (1=Yes) & $\begin{array}{c}1.990 \\
{[0.029]}\end{array}$ & $\begin{array}{c}1.971 \\
{[0.038]}\end{array}$ & $\begin{array}{c}2.014 \\
{[0.045]}\end{array}$ & 0.803 \\
\hline Well is individually owned ( $1=$ Yes) & $\begin{array}{c}2.985 \\
{[0.052]}\end{array}$ & $\begin{array}{c}2.963 \\
{[0.071]}\end{array}$ & $\begin{array}{c}3.012 \\
{[0.076]}\end{array}$ & 0.811 \\
\hline Number of observations & & & & 862 \\
\hline F-test of joint significance (p-value) & & & & 0.349 \\
\hline \multicolumn{5}{|l|}{ Panel C: Baseline HH survey, eligible farmers } \\
\hline \multicolumn{5}{|l|}{ Other characteristics of plot owner } \\
\hline Plot owner is male ( $1=$ Yes $)$ & $\begin{array}{c}0.785 \\
{[0.014]}\end{array}$ & $\begin{array}{c}0.782 \\
{[0.019]}\end{array}$ & $\begin{array}{c}0.790 \\
{[0.021]}\end{array}$ & 0.891 \\
\hline Age of plot owner (years) & $\begin{array}{l}49.219 \\
{[0.409]}\end{array}$ & $\begin{array}{l}49.735 \\
{[0.562]}\end{array}$ & $\begin{array}{l}48.595 \\
{[0.594]}\end{array}$ & 0.234 \\
\hline Caste of plot owner is forward ( $1=$ Yes) & $\begin{array}{c}0.498 \\
{[0.017]}\end{array}$ & $\begin{array}{c}0.468 \\
{[0.023]}\end{array}$ & $\begin{array}{c}0.533 \\
{[0.025]}\end{array}$ & 0.135 \\
\hline Years of education of plot owner & $\begin{array}{c}4.331 \\
{[0.150]}\end{array}$ & $\begin{array}{c}4.305 \\
{[0.207]}\end{array}$ & $\begin{array}{c}4.362 \\
{[0.218]}\end{array}$ & 0.894 \\
\hline \multicolumn{5}{|l|}{ Other characteristics of reference plot } \\
\hline Share of reference plot area cultivated in Rabi $2015 / 16(0-1)$ & $\begin{array}{c}0.964 \\
{[0.004]}\end{array}$ & $\begin{array}{c}0.958 \\
{[0.006]}\end{array}$ & $\begin{array}{c}0.970 \\
{[0.006]}\end{array}$ & 0.266 \\
\hline Grew wet crop in reference plot in Rabi 2015/16 (1=Yes) & $\begin{array}{c}0.087 \\
{[0.010]}\end{array}$ & $\begin{array}{c}0.110 \\
{[0.014]}\end{array}$ & $\begin{array}{c}0.059 \\
{[0.012]}\end{array}$ & $0.015^{* *}$ \\
\hline Number of functioning wells in reference plot & $\begin{array}{c}1.029 \\
{[0.006]}\end{array}$ & $\begin{array}{c}1.030 \\
{[0.008]}\end{array}$ & $\begin{array}{c}1.028 \\
{[0.008]}\end{array}$ & 0.741 \\
\hline Number of functioning wells in adjacency (exc. reference plot) & $\begin{array}{c}1.563 \\
{[0.039]}\end{array}$ & $\begin{array}{c}1.623 \\
{[0.051]}\end{array}$ & $\begin{array}{c}1.490 \\
{[0.059]}\end{array}$ & 0.121 \\
\hline \multicolumn{5}{|l|}{ Other characteristics of main well in the reference plot } \\
\hline Flow at start of Rabi 2015/16 & $\begin{array}{c}0.978 \\
{[0.003]}\end{array}$ & $\begin{array}{c}0.978 \\
{[0.004]}\end{array}$ & $\begin{array}{c}0.978 \\
{[0.005]}\end{array}$ & 0.624 \\
\hline Intra-flow in Rabi 2015/16 & $\begin{array}{c}0.349 \\
{[0.007]}\end{array}$ & $\begin{array}{c}0.353 \\
{[0.010]}\end{array}$ & $\begin{array}{c}0.343 \\
{[0.011]}\end{array}$ & 0.326 \\
\hline Pipe width & $\begin{array}{c}2.366 \\
{[0.013]}\end{array}$ & $\begin{array}{c}2.385 \\
{[0.018]}\end{array}$ & $\begin{array}{c}2.344 \\
{[0.017]}\end{array}$ & $0.058^{*}$ \\
\hline Number of observations & & & & 862 \\
\hline F-test of joint significance (p-value) & 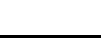 & & 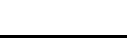 & $0.036^{* *}$ \\
\hline
\end{tabular}


Table 2. Minimum Detectable Effects

\begin{tabular}{lccc}
\hline \hline & Mean & SD & MDE \\
\cline { 2 - 4 } Total area irrigated by reference well (acres) & 3.08 & 1.97 & 3.28 \\
Share of reference plot area under wet crops (proportion) & 0.08 & 0.26 & $6 \%$ \\
& & & 0.10 \\
& 0.03 & 0.17 & 0.05 \\
Water sale to adjacent plot (well-level probability) & & & $57 \%$ \\
Adjacency area under water contract (acres) & 0.14 & 0.67 & 0.26 \\
& & & $84 \%$ \\
\hline
\end{tabular}

Note: This table contains the MDEs at $80 \%$ power and 5\% significance using a sample size of 400 treated farmers. Assumes one-sided tests. Percentages are effect sizes relative to baseline mean. 
Randomization checks using filter survey data

\begin{tabular}{|c|c|c|c|c|}
\hline \multicolumn{5}{|l|}{ Panel A: Filter survey sample } \\
\hline & (1) & (2) & (3) & (4) \\
\hline & \multicolumn{4}{|c|}{$=1$ if treated } \\
\hline \multirow[t]{2}{*}{ Well was sunk after 2011 (1=Yes) } & -0.005 & $-0.205^{* * *} *$ & -0.025 & 0.073 \\
\hline & $(0.040)$ & $(0.074)$ & $(0.097)$ & $(0.052)$ \\
\hline \multirow[t]{2}{*}{ Well is individually owned ( $1=$ Yes) } & $-0.063 * *$ & -0.091 & -0.074 & -0.049 \\
\hline & $(0.031)$ & $(0.058)$ & $(0.079)$ & $(0.041)$ \\
\hline \multirow[t]{2}{*}{ Reference plot area (acres) } & -0.015 & -0.068 & -0.012 & -0.038 \\
\hline & $(0.022)$ & $(0.056)$ & $(0.033)$ & $(0.042)$ \\
\hline \multirow[t]{2}{*}{ Family total landholdings (acres) } & -0.000 & -0.015 & 0.020 & 0.020 \\
\hline & $(0.011)$ & $(0.014)$ & $(0.035)$ & $(0.020)$ \\
\hline Observations & 1,153 & 283 & 250 & 620 \\
\hline R-squared & 0.009 & 0.044 & 0.005 & 0.007 \\
\hline Districts & All & Anantapur & Guntur & Kadapa \\
\hline District FE & Yes & No & No & No \\
\hline $\mathrm{p}$-value of joint significance & 0.266 & 0.007 & 0.847 & 0.372 \\
\hline \multicolumn{5}{|c|}{ Panel B: Household survey sample, eligible farmers } \\
\hline & (1) & (2) & (3) & (4) \\
\hline & \multicolumn{4}{|c|}{$=1$ if treated } \\
\hline \multirow[t]{2}{*}{ Well was sunk after 2011 (1=Yes) } & -0.020 & $-0.185^{* *}$ & -0.037 & 0.056 \\
\hline & $(0.046)$ & $(0.088)$ & $(0.098)$ & $(0.063)$ \\
\hline \multirow[t]{2}{*}{ Well is individually owned ( $1=$ Yes) } & $-0.071 * *$ & $-0.126^{*}$ & -0.077 & -0.059 \\
\hline & $(0.036)$ & $(0.073)$ & $(0.082)$ & $(0.049)$ \\
\hline \multirow[t]{2}{*}{ Reference plot area (acres) } & -0.006 & -0.055 & -0.013 & -0.015 \\
\hline & $(0.024)$ & $(0.068)$ & $(0.034)$ & $(0.050)$ \\
\hline \multirow[t]{2}{*}{ Family total landholdings (acres) } & 0.006 & -0.023 & 0.020 & $0.045^{*}$ \\
\hline & $(0.013)$ & $(0.017)$ & $(0.035)$ & $(0.023)$ \\
\hline Observations & 862 & 189 & 237 & 436 \\
\hline R-squared & 0.01 & 0.054 & 0.006 & 0.013 \\
\hline Districts & All & Anantapur & Guntur & Kadapa \\
\hline District FE & Yes & No & No & No \\
\hline p-value of joint significance & 0.349 & 0.024 & 0.818 & 0.224 \\
\hline
\end{tabular}

Note: robust standard errors in parentheses. $* * * \mathrm{p}<0.01,{ }^{*} \mathrm{p}<0.05,{ }^{*} \mathrm{p}<0.1$ 


\begin{tabular}{|c|c|c|c|c|}
\hline \multirow[b]{2}{*}{ Characteristics of plot owner } & \multicolumn{4}{|c|}{$\begin{array}{l}(1) \\
=1 \text { if applied to drip imigation system }\end{array}$} \\
\hline & & & & \\
\hline \multirow[t]{2}{*}{ Plot owner is male (1=Yes) } & 0.003 & -0.013 & 0.108 & -0.052 \\
\hline & $(0.068)$ & $(0.183)$ & $(0.252)$ & $(0.087)$ \\
\hline \multirow[t]{2}{*}{ Age of plot owner (years) } & -0.004 & -0.006 & -0.005 & -0.001 \\
\hline & $(0.002)$ & $(0.005)$ & $(0.004)$ & $(0.004)$ \\
\hline \multirow[t]{2}{*}{ Caste of plot owner is forward (1=Yes) } & 0.025 & 0.060 & -0.110 & 0.102 \\
\hline & $(0.049)$ & $(0.107)$ & $(0.092)$ & $(0.075)$ \\
\hline \multirow{2}{*}{ Years of education of plot owner } & & & & \\
\hline & $(0.007)$ & $(0.015)$ & $(0.012)$ & $(0.010)$ \\
\hline \multirow[t]{2}{*}{ Plot owner total landholdings (acres) } & 0.000 & 0.001 & 0.001 & 0.015 \\
\hline & $(0.012)$ & $(0.028)$ & $(0.018)$ & $(0.040)$ \\
\hline [Filter survey] Reference plot area (acres) & $\begin{array}{r}-0.018 \\
(0.033)\end{array}$ & $\begin{array}{c}0.116 \\
(0.092)\end{array}$ & $\begin{array}{r}-0.020 \\
(0.042)\end{array}$ & $\begin{array}{r}-0.038 \\
(0.074)\end{array}$ \\
\hline \multirow[t]{2}{*}{ Fully cultivated reference plot in Rabi 2015/16 (1=Yes) } & 0.038 & 0.040 & -0.132 & 0.094 \\
\hline & $(0.071)$ & $(0.114)$ & $(0.199)$ & $(0.118)$ \\
\hline \multirow[t]{2}{*}{ Grew wet crop in reference plot in Rabi 2015/16 (1=Yes) } & -0.112 & -0.084 & & -0.140 \\
\hline & $(0.110)$ & $(0.242)$ & $(0.106)$ & $(0.136)$ \\
\hline \multirow[t]{2}{*}{ Number of functioning wells in reference plot } & 0.073 & 0.120 & 0.038 & 0.058 \\
\hline & $(0.133)$ & $(0.217)$ & $(0.203)$ & $(0.324)$ \\
\hline \multirow{2}{*}{ Number of functioning wells in adjacency (exc. reference plot) } & & -0.019 & -0.033 & -0.050 \\
\hline & $(0.022)$ & $(0.041)$ & $(0.038)$ & $(0.036)$ \\
\hline \multicolumn{5}{|l|}{ Characteristics of main well in reference plot in Rabi $2015 / 16$} \\
\hline \multirow[t]{2}{*}{ Well flow } & -0.219 & -0.128 & -0.094 & -0.480 \\
\hline & $(0.208)$ & $(0.161)$ & $(0.232)$ & $(0.516)$ \\
\hline \multirow[t]{2}{*}{ Well intra-flow } & -0.180 & -0.230 & -0.058 & $-0.336^{*}$ \\
\hline & $(0.123)$ & $(0.370)$ & $(0.195)$ & $(0.184)$ \\
\hline \multirow[t]{2}{*}{ Pipe width } & -0.015 & -0.144 & 0.081 & 0.006 \\
\hline & $(0.075)$ & $(0.203)$ & $(0.162)$ & $(0.105)$ \\
\hline \multirow[t]{2}{*}{ Well is individually owned $(1=\mathrm{Yes})$} & -0.066 & -0.115 & $-0.179 * *$ & 0.008 \\
\hline & $(0.055)$ & $(0.103)$ & $(0.087)$ & $(0.089)$ \\
\hline Observations & 384 & 79 & 118 & 187 \\
\hline R-squared & 0.090 & 0.092 & 0.111 & 0.091 \\
\hline Districts & All & Anantapur & Guntur & Kadapa \\
\hline District FE & Yes & & No & \\
\hline Mean dep var & 0.648 & 0.785 & 0.712 & 0.551 \\
\hline SD dep var & 0.478 & 0.414 & 0.455 & 0.499 \\
\hline F-test of joint significance ( $p$-value) & 0.001 & 0.143 & 0.000 & 0.202 \\
\hline
\end{tabular}


$\underline{\text { Reference plot cultivation and agricultural profits }}$

\begin{tabular}{|c|c|c|c|c|c|c|c|c|}
\hline & $\overline{\mathrm{N}}$ & Mean & 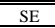 & Min & 2 25th & $\begin{array}{l}\text { 50th } \\
\end{array}$ & 7 75th $^{2}$ & Max \\
\hline \multicolumn{9}{|l|}{ Area and cultivation } \\
\hline Area cultivated (acres) & 990 & 2.14 & 0.94 & 0.38 & 1.50 & 2.00 & 2.50 & 5.00 \\
\hline Share of plot cultivated (cultivated area/plot area) & 990 & 0.96 & 0.14 & 0.20 & 1.00 & 1.00 & 1.00 & 1.00 \\
\hline Share of area cultivated devoted to wet crops & 990 & 0.08 & 0.26 & 0.00 & 0.00 & 0.00 & 0.00 & 1.00 \\
\hline \multicolumn{9}{|l|}{ Yields (quintals/area cultivated) } \\
\hline Harvested & 990 & 15.65 & 16.44 & 0.00 & 6.50 & 12.00 & 18.52 & 116.02 \\
\hline Sold & 990 & 14.55 & 15.18 & 0.00 & 6.00 & 10.94 & 17.00 & 100.00 \\
\hline Total revenue (000s rupees/area cultivated) & 990 & 57.95 & 63.31 & 0.00 & 20.13 & 34.77 & 75.00 & 403.88 \\
\hline Total cost (000s rupees/area cultivated) & 990 & 29.25 & 15.71 & 4.95 & 18.33 & 25.65 & 35.78 & 108.39 \\
\hline Transportation cost & 990 & 1.30 & 1.32 & 0.00 & 0.50 & 0.89 & 1.67 & 11.40 \\
\hline Output transportation & 990 & 0.80 & 0.95 & 0.00 & 0.25 & 0.50 & 1.00 & 9.21 \\
\hline Input transportation & 990 & 0.50 & 0.64 & 0.00 & 0.16 & 0.33 & 0.60 & 9.00 \\
\hline Input cost & 990 & 20.27 & 11.41 & 0.85 & 12.53 & 17.43 & 24.56 & 86.10 \\
\hline Seeds & 990 & 4.29 & 3.55 & 0.00 & 2.00 & 3.50 & 5.67 & 46.67 \\
\hline Chemical fertilizers & 990 & 3.87 & 3.42 & 0.00 & 1.68 & 2.67 & 4.90 & 23.53 \\
\hline Organic fetilizers & 990 & 2.50 & 2.50 & 0.00 & 0.93 & 1.80 & 3.38 & 21.01 \\
\hline Irrigation & 990 & 0.93 & 1.25 & 0.00 & 0.13 & 0.60 & 1.20 & 11.54 \\
\hline Pesticides & 990 & 3.39 & 3.98 & 0.00 & 1.00 & 1.81 & 4.17 & 32.91 \\
\hline Herbicides & 990 & 0.54 & 0.76 & 0.00 & 0.00 & 0.31 & 0.85 & 7.33 \\
\hline Bullock & 990 & 2.64 & 1.90 & 0.00 & 1.33 & 2.23 & 3.40 & 14.50 \\
\hline Tractor & 990 & 2.12 & 1.72 & 0.00 & 1.00 & 1.72 & 2.79 & 17.40 \\
\hline Labor cost (exc. family labor) & 990 & 7.67 & 5.44 & 0.00 & 4.06 & 6.00 & 9.43 & 53.57 \\
\hline Total profits per acre (000s rupees/area cultivated) & 990 & 28.69 & 57.60 & -72.69 & -3.38 & 10.16 & 41.00 & 350.95 \\
\hline \multicolumn{9}{|l|}{ By-products (000s rupees/area cultivated) } \\
\hline Value of by-products & 990 & 1.44 & 2.59 & 0.00 & 0.00 & 0.00 & 2.08 & 26.67 \\
\hline Value of by-products sold & 990 & 0.75 & 1.72 & 0.00 & 0.00 & 0.00 & 0.90 & 25.00 \\
\hline
\end{tabular}

Note: Only cultivation on reference plot. Yields, revenues and profits variables were winsoridzed at the 99th percentile. There are no production data avilable 
Additional tabulations

\begin{tabular}{llr}
\hline \hline Variable & Data level & Mean \\
\hline$\%$ of cultivated plots in the adjacency (exc. reference plot) & Adjacency & 0.66 \\
$\%$ of plots with functioning well in the adjacency (exc. reference plot) & Adjacency & 0.51 \\
\hline
\end{tabular}

Notes: number are based on baseline survey data 